\title{
ІНТЕРАКТИВНИЙ АСПЕКТ СУЧАСНОЇ ВОКАЛЬНОЇ ОСВІТИ ВЧИТЕЛІВ НА ПРИКЛАДІ МЕТОДУ ЕVТ
}

\author{
Вікторія Зотова \\ аспірант \\ кафедри теорії та методики музичного навчання \\ хорового співу та диригування \\ факультету мистецтв імені А. Т. Авдієвського \\ Національний педагогічний університет імені М. П. Драгоманова \\ м. Київ, Україна \\ ORCID ID 0000-0003-0548-1774 \\ vanilvetochka@gmail.com
}

\begin{abstract}
Анотація. У статті розглянуто унікальну вокальну методику всесвітньо відомого, видатного педагога, вокаліста, медика та науковця др. Джо Естіл. Проаналізовано ключові аспекти іiі діяльності, що представляють міцний теоретико-практичний фундамент для розвитку конкурентноспроможної української вокальної школи майбутнього в контексті інтеграційно-європейських тенденцій розвитку суспільства. Розкрито сутність понять: «методика EVT», «інноваційне навчання», досліджено комплекс прийомів теоретикопрактичного курсу Джо Естіл для розвитку вокального голосу.

Проаналізовано міждисциплінарний характер методики та вивчено історичні матеріали, що стали підгрунтям для іiї становлення та розвитку. 3'ясовано цінність практичної спадщини методики др. Джо Естіл для розвитку науки та вокальної педагогіки у світі та в Україні зокрема.

Ключові слова: вокальна методика Джо Естіл; EVT; новітні педагогічні технології; інноваційні методи; анатомія; універсальна методика формування та розвитку вокальних навичок.
\end{abstract}

Постановка проблеми в загальному вигляді. Сучасне вокальне мистецтво $є$ синтезованим i багатовекторним в епоху стрімкого розвитку медіаіндустрії, коли домінантним фактором є свіжість та сучасність погляду суб’єкта мистецтва, запит споживача на конкретний вид творчого продукту та його комерційна успішність і якість. В одному спектаклі органічно співіснують театр, мюзикл, оркестр, а на великих сценах поп-зірки співпрацюють із хореографами, режисерами, постановниками спец-ефектів у прагненні створити шоу, що матиме своїх прихильників і мільйони переглядів на YouTube.

Але в центрі всіх перерахованих вище жанрів є один важливий елемент голос. Це інструмент, який актор, вокаліст, диктор має опановувати та розумно використовувати у своїй роботі, підтримуючи його весь час у робочому стані. Науковці досліджують його анатомічні особливості, функціональність, допомагаючи своїми відкриттями педагогам i вокалістам практично вдосконалювати якості цього тендітного інструменту. Усі ці області 
застосування голосу об’єднала в своїй науково-педагогічній творчій діяльності непересічна особистість і видатний педагог др. Джо Естіл (Joe Estill).

EVT (Estill Voice Training) - професійна авторська методика постановки голосу, яка складається з двох курсів: «Фігури (вправи) для контролю голосу» та «Комбінації фігур для шести якостей голосу», покликаний ефективно поєднувати злагоджену роботу здорового вокального апарату 3 набуттям комплексу технічних навичок вокальної майстерності. Співпраця вчителя i студента згідно з настановами методики організується без домінантного аспекту, де викладач демонструє широкий спектр технічних можливостей голосу, а учень сам вирішує, як саме йому використовувати цей практично-теоретичний матеріал.

До України EVT прийшов з Італії лише минулого року, хоча в Америці широковідомий упродовж 30 останніх років і лежить в основі провідних вокально-педагогічних практик. Праці Джо Естіл та її послідовників із тих, що $є$ у публічному доступі, можна знайти в бібліотеках Великобританії, Австралії, Америки, Італії мовою оригіналу.

Інтерес до вивчення цього питання серед педагогів-вокалістів в Україні 3 кожним днем зростає з огляду на усвідомлення теоретико-практичної цінності методики др. Джо Естіл і ефективності результатів ії діяльності впродовж трьох десятиліть у світі. Не дивує і той факт, що саме США $є$ центром всесвітнього шоу-бізнесу через той факт, що саме в цій країні народилися та розвинулися провідні викладацькі методики на кшталт EVT. Поєднання подібних зразків сучасної вокальної школи з творчим потенціалом українців може подарувати світу безліч нових талантів і збагатити науково-педагогічну та вокальнометодичну скарбницю актуальними працями.

Аналіз останніх досліджень і публікацій. Аналізу чисельних досліджень др. Джо Естіл присвячуються всесвітні конференції, симпозіуми, які проводяться в провідних університетах світу таких, як Гарвард. Лектори з багатьох країн із широким науковим спектром дисциплінарних інтересів (від вокалістів i педагогів до вчених-медиків, фізиків-акустиків, фонопедів, акторів, отоларингологів, дифектологів, фоніатрів) зацікавлені у вивченні роботи голосового апарату. Але це питання все ще залишається поза зоною інтересів вітчизняних науковців вищеперерахованих галузей, тому що участь у семінарах, заняттях EVT, ураховуючи, що вони проводяться виключно на комерційній основі, може дозволити собі лише обмежене коло бажаючих. Ураховуючи цей момент і маючи бажання вивчати цю тему, слід звертатись до праць американських, британських, російських учених i педагогів-практиків, вокалістів-блогерів, що займались вивченням цього питання (Д. Ашрапової, 
П. Бабакової, А. Сгорової, Е. Дорнгоф, М. Клімек, К. Стейнхауер, А. Мартінеза, К. Сальтсбурі, К. Штайнгаузер, К. Телліс, Т. Ллойда), і, зрештою, до праць самої Джо Естіл. Першими роботами про EVT стали «The Estill Voice Model» та «Figures for Voice», що з'явилися в публічному доступі завдяки співтовариству др. Джо Естіл та професора віцепрезидента міжнародної асоціації Estill Voice International M. Макдональд Кімлек. Всесвітнє визнання у вокальній педагогіці др. Джо Естіл принесли дослідження манери «Belting». Завдяки співу в ній вокалістка зуміла відокремити механіку звуку від художньо-естетичних упереджень. Публікації вченого-дослідника із 30-річним досвідом в області акустики, вокальної фізіології та педагогіки були надруковані у відомих наукових виданнях: «Jornal of Voice», «Medical Problem of Performing Arts», «Vocal Fold Physiology: Voice Quality Control», «Vocal Fold Physiology: Controlling Complexity and Chaos».

Вивчаючи роботи др. Джо Естіл, компетентні праці решти педагогів та вчених, присвячених дослідженню нашого питання, можна стверджувати, що сучасна вокальна школа може відкрити в цій науково-педагогічній літературній спадщині перспективне підгрунтя для виникнення і розвитку новітніх вокальних шкіл, інноваційних методів та новітніх технологій у карбуванні професійних голосів, зважаючи на національний природний вокальний потенціал українців. Унікальність методики Джо Естіл та міцна витривалість і краса українських голосів спроможні утворити ефективний симбіоз та подарувати світу в тісному тандемі нових зірок світового гатунку як у жанрі академічного вокалу, так i виконавців джазу, співаків сучасної музики. Міждисциплінарність підходів роботи в області акустики, дефектології, медицини, педагогіки надихатиме українських учених на нові спільні відкриття, що пов'язані $з$ дослідженнями Естіл стосовно природи звука.

Формулювання цілей статті. Дослідити цінність та ефективність інтерактивної вокальної методики Джо Естіл на предмет актуальності використання іï в сучасній українській вокальній педагогіці.

Методи дослідження. У дослідженні було застосовано методи теоретичного абстрагування, аналізу та синтезу основних понять і прийомів вокальної школи Джо Естіл у контексті сучасних тенденцій вокальної педагогіки; проведено концептуальний аналіз матеріалів науково-практичних конференцій, майстер-класів і науково-методичної літератури: статей, рефератів, присвячених темі, та з'ясовано інтерактивність підходів в організації навчального процесу за оригінальною вокальною методикою др. Джо Естіл.

Результати дослідження. Др. Джо Естіл була оперною співачкою, розуміння процесу звуковидобування якої базувалось лише на емпіричному 


\section{B. 3OTOBA}

Інтерактивний аспект сучасної вокальної освіти вчителів на прикладі методу EVT

досвіді на початку вокальної кар'єри, але теоретична складова цього питання мала прогалини, залишаючи багато питань без відповідей. Наведемо одну з цитат самої вченої: «Я ніколи не знала, що саме я роблю, для того щоб так красиво співати, тому почала викладати вокал із тих самих причин, із яких це робить більшість моїх колег - мені потрібні були гроші. I, як і багато вчителів-початківців, я нічого не знала про викладання постановки голосу, тому я зібрала багато книг і думала, що буду вчитися. Все, що я дізнавалася, було: а) я розуміла книжки не більше ніж ті, хто викладав колись вокал мені; б) між ними мало домовленості як у мовних, так і в понятійних моментах; і с) те, що я читаю, не має нічого спільного 3 тим, що я думаю і роблю, коли так красиво співаю. Я вирішила, проігнорувавши книги, проаналізувати те, що роблю, і якщо я зможу, змусити своїх студентів співати так само добре, як я, тоді я стану хорошим учителем» (Salsbury, 2014).

Джо Естіл народилася в сім’ї італійських емігрантів у США в 1921 році і почала заняття вокалом у віці 4 років. Створити успішну оперну кар'єру їй не вдалося, не зважаючи на непересічні вокальні данні іiі природного меццосопрано, але поєднання вокальних навичок із професією лікаря-фоніатра відкрили перед нею великі перспективи наукової та педагогічної діяльності.

Переглянувши старі теорії на процес звуковидобування, які базувалися лише на емпіричному досвіді педагогів-вокалістів та їхніх особистих відчуттях цього процесу до 80-х років минулого століття, вона створила свою інноваційну методику навчання вокалу, перед цим ретельно дослідивши анатомічну та практичну функції вокального апарату. Новаторство iï поглядів полягало в переконанні, що за наявності необхідних знань про роботу вокального апарату, співати можуть всі! (EVT, 2017).

Будучи оперною співачкою, вона не мала впевненості в готовності співати кожного разу, коли виходила на сцену і не відчувала себе там комфортно. Мінлива природа цього явища примусила ii шукати шляхи вирішення цієї проблеми. Уперше вона мала можливість спостерігати роботу голосового апарату за допомогою ендоскопу в Нью-Йорку. Др. Джо Естіл продовжила свою наукову діяльність у Сиракузах, де її було призначено вокальним інструктором кафедри отоларингології в медичному центрі. У 2004 році др. Джо Естіл отримала почесний докторський ступінь Університету Східної Англії (University of East Anglia).

Результатом продуктивної 10-річної наукової діяльності др. Джо Естіл стала альтернативна методика EVT, яку авторка успішно почала перевіряти на практиці, навчаючи вокалістів, викладачів та всіх охочих дізнатися більше про природу і технічні можливості голосу.

Метод др. Джо Естіл - інтенсив-методика, в основі якої лежать наукові

Професіоналізм педагога: теоретичні й методичні аспекти. - Вип. 11. - Слов'янськ, 2019. 
Інтерактивний аспект сучасної вокальної освіти вчителів на прикладі методу EVT

дослідження, сприяє оптимізації навчального процесу та його структурованості, розвиває креативність i комунікативність студентів, здатність приймати нестандартні самостійні рішення і характеризують EVT як інтерактивний метод.

Термін «інтерактивність» (з англ. inter - взаємний, act - діяти). Інтерактивне навчання побудоване на взаємодії учня з навчальним оточенням та навчальним середовищем, що слугує сферою набутого досвіду. Педагог не дає готових знань, але спонукає учасників до самостійного пошуку. Порівняно 3 традиційним навчанням в інтерактивному змінюється взаємодія педагога і учня: активність педагога поступається місцем активності учнів, а завданням педагога стає створення умов для їхньої реалізації (Гончаренко, 2011).

Сучасні інтерактивні технології в музичній освіті в контексті підготовки викладачів-вокалістів до професійної діяльності базуються на індивідуальному підході з активним залученням до навчального процесу всіх суб'єктів взаємодії. EVT як методика розроблена автором для навчання викладачів не у загальноприйнятому розумінні «викладач-маестро», а як наставників-тренерів, інструкторів, сертифікованих спеціалістів з усього світу. Результатом їхньої підготовки є складні фінальні іспити, де кожен кандидат має продемонструвати знання не лише теоретичного матеріалу курсу, але й вміння практично його застосовувати - заспівати наочно всі голосові прийоми («якості» голосу), вправи. EVT передусім допомагає викладачеві в плануванні поетапної організації навчального процесу з передбаченням ефекту його кінцевого результату.

$\mathrm{He}$ існує жорстких меж у систематичності відвідувань курсів EVT, ураховуючи їхню технічну складність і необхідність додаткового часу для індивідуального усвідомлення вже після роботи з інструктором-методистом. Студент може відвідати один курс, а згодом - другий, чи взагалі повторити перший за необхідністю більш грунтовного розуміння методики. Але якщо студент уже розпочав заняття за методом др. Джо Естіл, то впродовж курсу він має самовдосконалюватись щоденно, досліджуючи свій вокальний апарат і його можливості через комплекс наданих вправ і теоретичної інформації.

Момент активного співробітництва між інструктором і студентом $\epsilon$ запорукою здорового мікроклімату процесу навчання, бо спрямований на вивільнення творчої енергії останнього, звільненню набутих комплексів, підвищенню самооцінки. Студент має позбутися життєвих упереджень і пізнати не лише свій вокальний апарат, але й налагодити органічний зв'язок зі своїм тілом, навчитися керувати його м'язами, складовими вокального апарату, що беруть участь у процесі звукоутворення. Тренування м'язової пам'яті допомагатиме студенту ефективно і швидко налаштовувати вокальний апарат до роботи і підтримувати його здоровим.

(ㄱ ДВНЗ «Донбаський державний педагогічний університет» 
Інтерактивний аспект сучасної вокальної освіти вчителів на прикладі методу EVT

На цих вокальних заняттях має місце суб'єкт-суб'єктний інтерактивний характер педагогічного спілкування за умови активності всіх дотичних учасників справи його творення з виключенням домінантного аспекту. Викладач ретельно ознайомлює студента 3 анатомією вокального тракту, демонструючи фото та відеодокази його роботи, пропонує технічні вправи для розвитку вокальної техніки - «фігури для голосу» та для вивільнення м'язів вокального апарату. Надаючи ключі до користування всім арсеналом засобів і прийомів авторського курсу др. Джо Естіл, викладачі $є$ лише трансферними провідниками до креативного процесу побудови голосу студента, бо саме останній займається творенням свого інструменту, обираючи із запропонованих викладачем засобів і шляхів поліпшення вокальної майстерності лише ті, що йому дійсно потрібні. Крім того, курс не наголошує на постійності роботи лише одного викладачанаставника, і студент при бажанні може займатися з іншими тренерами заради підвищення ефективності набутих знань, але за обов'язкової умови гігієни голосу.

Концепцію EVT структуровано в три навчальні етапи: технічна майстерність, артистична майстерність - важливий компонент, що в поєднанні 3 першою складовою робить можливим досягнення фінального навчального етапу - «магії» виконання - кульмінації всієї методики.

Перший розділ курсу - технічна майстерність - фундаментально ознайомлює з анатомією вокального апарату, побудовою його окремих структур, м'язів, залучених до звукоутворення та механізмів їхньої взаємодії. Через усвідомлення всіх нюансів роботи складного голосового інструменту студент вчиться контролювати його структури: положення гортані, роботу персневидного та щитовидного хрящів, основних і хибних зв'язок, язика, губ, піднебіння, органів вокального дихання.

Ключами до розуміння механізму звукоутворення, на думку др. Джо Естіл, можуть бути звичайні життєві процеси: сміх, що виникає завдяки розведенню хибних зв'язок, а при опусканні щитовидного хряща людина сміється чи їі голос забарвлюється жалібними інтонаціями (Ашрапова, 2017). Якщо використати ці моменти як інструменти до розуміння природи голосового апарату, то можна збагнути і мову співу. Одного разу, проводячи урок академічного вокалу, др. Джо Естіл відвідала студентка 3 дитиною, і коли викладач заспівала, показуючи чергову вправу, дитя поцікавилось чому жінка-викладач плаче? Цей випадок примусив учену замислитись над зв'язком асоціацій, звичайних життєвих процесів, що людина переживає неодноразово протягом кожного дня, не намагаючись аналізувати, бо це дуже органічні для неї процеси (плач, розмова, сміх, крик, шепіт) із роботою вокального апарату і розгледіти їх як

Професіоналізм педагога: теоретичні й методичні аспекти. - Вип. 11. - Слов'янськ, 2019. 
Інтерактивний аспект сучасної вокальної освіти вчителів на прикладі методу EVT

найзрозуміліші інструменти в керуванні голосом. До моменту дослідницької діяльності були лише здогадки вченої з приводу можливості керування голосом у такий спосіб, але дослідницька діяльність розвіяла всі питання і затвердила правильність цієї думки, і др. Джо Естіл згодом систематизувала способи звукоутворення у вокальні «якості» голосу:

- плач (cry) - легкий, світлий, інтонаційно жалібний звук;

- ридання (sob) - плач із низьким положенням гортані, більш темного забарвлення ніж «сry»;

- фальцет (субтон) - звук, що утворюється завдяки придихальній манері;

- $\quad$ мова (speech) - розмовний голос;

- твенг (twang) - яскравий звук на високій форманті, EVT метод розглядає назальний та оральний твенг. Зазвичай останній видобувається складніше, має металевий тембральний відтінок. Назальний має досить щільне звучання через використання носового резонатору, але ступінь його міцності можна регулювати завдяки вокальному диханню;

- белтінг - «вокальний крик» на опорі; цей вокальний тембр уперше описала др. Джо Естіл;

- $\quad$ fry - «смажений» - звук, що утворюється на розслабленому смиканні зв'язок, коли їхні коливання неперіодичні (Ашрапова, 2017).

Завдяки вмінню контролювати вищеперераховані вокальні «якості» голосу можна опанувати хвилювання під час виступу. Упевненість у використанні можливостей голосу дозволяє виконавцю відчути комфорт на сцені. Крім того, уміле поєднання цих «якостей» допомагає вокалістам та педагогам знаходити нові «вокальні прикраси», збагачуючи свою виконавську майстерність.

На другому етапі курсу EVT карбується артистична майстерність студента, і це передбачає вдосконалення не лише засобів акторської виразності, органіку поведінки на сцені, але передусім зводиться до пошуку балансу між виконавською інтерпретацією твору та теоретико-історичними особливостями стилю, біографічною інформацією щодо автора і його настанов. Завданням цього етапу $є$ виховання почуття міри у врегулюванні ступеня дозволеності у творчому трактуванні змісту твору студентом.

На третьому етапі артист налагоджує спільну мову з глядачем, i саме в цей момент має народжуватися шоу в його «магічному» значенні - лише контактом із публікою справа не вичерпується, тут є місце імпровізації зі змінами в сценарії, художній виразності зі справжністю емоцій - політ творчості - режисер такого дійства. Одночасно професіонал своєї справи може проконтролювати технічні 
Інтерактивний аспект сучасної вокальної освіти вчителів на прикладі методу EVT

моменти, акустику приміщення, психологічну специфіку публіки - усі необхідні складові успішного концерту (Бабакова, 2018).

Усі три етапи EVT $\epsilon$ базовою частиною семінарів, курсів, які насамперед характеризуються змістовністю, інтенсивністю і об'ємом переданих під час їхнього проведення знань, стимулюють розвиток творчого мислення студента, допомагають у визначенні завдання і мети навчального процесу, у знаходженні шляхів вирішення проблем, пов'язаних із організацією виконавської діяльності.

На думку автора, EVT якість співу - характеристика кожного вокального голосу, яку не слід розглядати як позитивне чи негативне явище, а суто в сенсі того наявного факту, що подарувала людині природа і розвинула впродовж життя сама людина. Будь-які якості співу можуть бути використані як засоби виразності, незалежно від того, у якій вокальній манері співає студент, а відповідно до поставлених перед ним творчим завданням, стильовими особливостями твору і ступенем технічної майстерності самого студента.

Досліджуючи роботу методики, слід зазначити, що ії принципи базуються на чотирьох важливих складових:

- розуміння анатомічної побудови голосу - ключ до його контролю;

- дихання має бути вільним і взаємодіяти з рештою складових вокального апарату, які воно зустрічає на своєму шляху під час видиху;

- звукоутворення розпочинається до того моменту, як з'являється звук (саме тому так важливі м'язові відчуття, бо вони не лише передують аналізу самого звукоутворення, але й спонукають і стимулюють його покращення після аналізу);

- ефективність методики має місце за умови його розподілу на три основні етапи: технічна майстерність, артистична майстерність та «магія» виконання.

Навчання відбуваються за чітко визначеним планом методики, а отриманий студентом досвід та знання акумулюються, переосмислюються в самостійній роботі, випробовуються на практиці, рефлексуються.

Тематизм методики другорядний на відміну від значущості самого процесу навчання, бо він не просто пов'язаний із переусвідомленням і аналізом звичайних життєвих процесів: криком, плачем, сміхом, але і є один із них за своєю природністю - співом. Студент, знайомлячись із тонкощами вокального мистецтва опановує свій особистий інструмент - голос, відкриваючи його нові можливості спочатку для самого себе, а згодом дарує результати свого труда вдячному слухачеві.

Відзначимо індивідуальність підходу EVT, незважаючи на те, яким чином відбуваються навчання - у групі чи 3 особистим тренером - усі способи покликані утворити сприятливі умови для вміння налагоджувати студентом

Професіоналізм педагога: теоретичні й методичні аспекти. - Вип. 11. - Слов'янськ, 2019. 
Інтерактивний аспект сучасної вокальної освіти вчителів на прикладі методу EVT

передусім самостійну роботу, стимулювати пошук цікавих рішень у поєднанні акторської і вокально-технічної майстерності.

EVT - провідна авторська методика 3 інноваційною природою, де унікальність важко переоцінити, тому що вона розвиває студента як творчу багатогранну особистість. Цей момент підтверджує міждисциплінарний аспект методики - не лише розвитком вокальних здібностей обмежуються навчання EVT - головним завданням $є$ виховання артиста в багатовекторному сенсі, iз наданням навичок і знань з інших творчих дисциплін: акторської майстерності, мистецтвознавства, хореографії, режисури. Подібний науково-педагогічний досвід має зайняти належне місце в українській науці та педагогіці як апробований, спрямований на ефективність результату та особливо цінний у набутті професійної вокальної освіти українських учителів.

Висновки 3 дослідження й перспективи подальших розвідок у цьому напрямі. Становлення нової системи вокальної освіти відповідно до вимог евроінтеграційних процесів вимагає суттєвих змін інноваційного спрямування в підготовці майбутніх педагогів-вокалістів.

Сукупність способів і прийомів Estill Voice Training є однією з небагатьох у світі авторських вокальних методик, що виникла і розвинулася на науковому підгрунті. Новаторський і водночас індивідуальний підхід EVT може збагатити вже наявні зразки традиційних методик чи стати частиною вдосконалених програм сучасної вокально-педагогічної української школи, метою якої $\epsilon$ виховання професійних, висококваліфікованих кадрів у жанрі академічного співу та сучасних жанрів вокальної музики.

Розвиток творчого мислення студентів, інноваційні шляхи в організації майстер-класів, семінарів, доступність до інформаційного ресурсу останніх досліджень в області звуковидобування, змістовність теоретико-практичного матеріалу методики EVT покликані модернізувати вокальну освіту і створити шляхи для народження нових прогресивних, конкурентоспроможних методів у підготовці фахових педагогів, а міждисциплінарний аспект EVT сприятиме новим науковим відкриттям у вітчизняній медицині, вокальній педагогіці, акустиці та дефектології.

\section{СПИСОК ВИКОРИСТАНИХ ДЖЕРЕЛ}

1. Ашрапова, Д. Д. (2017). Инновации в вокальной педагогике. Вестник института мировых ичивилизаций, 15( 2), 15-21.

2. Бабакова, П. Н. (2018). Джо Эстилл и ее уникальный метод. Лучшая студенческая статья. Краснодар, Россия: КГУК. 188-191.

3. Гончаренко, С. (2011). Украйнський педагогічний енциклопедичний словник. (2), оновл. Рівне. Україна: Волинські Обереги.

4. EVT. (2017). Офіційний сайт Estill Voice Training. Взято 3 


\title{
B. 3ОTOBA
}

Інтерактивний аспект сучасної вокальної освіти вчителів на прикладі методу EVT

https://www.estillvoice.com/history/

5. McDonald Klimek Mary. (2005). Estill Voice Level One: Compulsory Figures for Voice Control. Piysburg. USA: Estill Voice Training Sistem International LLC.

6. Salsbury Katharine. (2014). Estill voice training: the key to holistic voice and speech training for the actor. Взято 3 https://scholarscompass.vcu.edu/cgi/viewcontent.cgi?article=4383\& context=etd

\section{INTERACTIVE ASPECT OF MODERN VOCAL EDUCATION OF TEACHERS ON THE EXAMPLE OF EVT METHOD}

\author{
Viktoriia Zotova \\ PhD Student of the Department of the Theory and Methodology of Musical \\ Education, Choir Singing and Conducting \\ Faculty of Arts named after Anatolii Avdiievskyi \\ National Pedagogocal Dragomanov Universiry \\ Kiyv, Ukraine \\ ORCID ID 0000-0003-0548-1774 \\ vanilvetochka@gmail.com
}

\begin{abstract}
The article is dedicated to the study of EVT's unique vocal methodology. This one was initiated and made known throughout the world as the Estill Voice Training by American opera singer of Italian origin, a certified phoniater, scientist, outstanding teacher Dr. Jo Estill. The works of other representatives of the scientific and pedagogical community in the field of dipectology, vocal pedagogy, otolaryngology, and acoustics related to the study of the scientific heritage of Dr. Jo Estil and his personal works in these areas are analyzed. His works were published in the most prestigious professional editions, for example in the "Chronicle of Otology, Rhinology and Laringology", "Medical Problems of Performing Art", and in the "Magazine of Voice".

The scientist investigated thoroughly the anatomy of the vocal apparatus and all its components in the interaction with the help of an endoscope, laggioscope, electromyography and electro-glotografy for the first technical opportunity to do it in the 80-s of the previous century. Dr. Joe Estill, one of the first among the teachers and scholars, emphasized the importance of false vocal cords in sound formation. The exercises developed by him for the improvement of the vocal skills named "Voice Figures" became the basis of the practical course of EVT, and their task is to learn conscious control of the individual muscles as a constituent part of the vocal apparatus.

Numerous conferences at major universities in the world, such as Harvard, are dedicated to the study of Dr. Joe Estil's scientific discoveries, literary heritage and its unique EVT method. Estill Voice Training is a course for vocal teachers, which has been used on all continents for over 25 years, the author and teacher Dr. Joe Estil trained certified vocalists, practicing teachers, and voice announcer speakers. This course is the base for vocal skills at many prestigious universities in the UK, Venezuela, Australia, Italy, Russia, in particular at the Conservatory of Caracas and the Royal Academy of Music in London.

The article clarifies the innovativeness of the EVT method in the context of the cooperation of the teacher-student and its main task: the combination of the harmonious work of a healthy vocal apparatus with the acquisition of a complex of technical methods of vocal skills. The teacher's personal feelings and his (her) empirical experience are not always effective in mastering the competence, and sometimes harmful for the student's vocal health or mental state due to the categorical, under-illiteracy and bias of the teacher. Dr. Joe Estil's school and its scientific and practical base will promote the development of an equally active relationship between a teacher and a student, without a dominant aspect, where a teacher will open a wide range of student performances without compromising his (her) physical and emotional health.
\end{abstract}

Професіоналізм педагога: теоретичні й методичні аспекти. - Вип. 11. - Слов’янськ, 2019. 


\section{B. 3OTOBA}

Інтерактивний аспект сучасної вокальної освіти вчителів на прикладі методу EVT

Key words: vocal methodology by Jo Estill; EVT; newest technologies; innovative method; anatomy; universal method of formation and development of vocal skills.

\section{REFERENCES}

1. Ashrapova, D. D. (2017). Innovation in vocal pedagogy. Vestnik instituta mirovykh tsivilizasiy, 15 (2), 15-21.

2. Babakova, P. N. (2018). Jo Estill and her unique method. Luchshaya studencheskaya statya. Krasnodar, Russia: KGUK. 188-191.

3. Honcharenko, S. (2011). Ukrainian pedagogical encyclopedic vocabulary. Rivne. Ukraine: Volynski Oberehy.

4. EVT. (2017). The official site of Estill Voice Training. Retrieved from https://www.estillvoice.com/history/

5. McDonald Klimek Mary. (2005). Estill Voice Level One: Compulsory Figures for Voice Control. Piysburg. USA: Estill Voice Training Sistem International LLC.

6. Salsbury, Katharine. (2014). Estill voice training: the key to holistic voice and speech training for the actor. Retrieved from https://scholarscompass.vcu.edu/cgi/viewcontent.cgi article=4383\&context=etd

\footnotetext{
Матеріали надійшли до редакції 01.11.2019 p.
} 